\title{
Time and Spatial Variability in Concentrations of Selected Pollutants in the New Bypass Rainwater Harvesting System
}

\author{
Tomasz Zubala $(\mathbb{D} \cdot$ Magdalena Patro
}

Received: 14 December 2020 / Accepted: 14 April 2021 / Published online: 10 May 2021

(C) The Author(s) 2021

\begin{abstract}
The level of pollution and the variability of rainwater runoff quality collected in reservoirs next to the new Lublin bypass (south-eastern Poland) were assessed in this scientific paper. In the rainwater harvesting and treatment system, two types of reservoirs with different construction, size and presence of pretreatment devices were used. Laboratory tests involved selected physical, oxygen, biogenic, salinity indicators, heavy metals and polycyclic aromatic hydrocarbons. Particularly large variability in concentrations included $\mathrm{NO}_{2}{ }^{-}, \mathrm{TP}, \mathrm{PO}_{4}{ }^{3-}, \mathrm{K}^{+}$and $\mathrm{Cl}^{-}$. Parameters decreasing the water quality were mainly conductivity, $\mathrm{BOD}_{5}, \mathrm{COD}$, $\mathrm{NO}_{2}{ }^{-}, \mathrm{TP}$ and $\mathrm{Cl}^{-}$. High concentrations of salt and phosphorus in collected rainwater require great care in final management (risk of salinization and eutrophication). In the second year of research, there was significant deterioration of water quality, which may result from different weather conditions and gradual accumulation of pollutants in new reservoirs. Not many significant differences were found in the quality of water collected in reservoirs with pre-treatment and without it. Loads of heavy metals and aromatic hydrocarbons in reservoirs were relatively small. However, these impurities have
\end{abstract}

T. Zubala $(\bowtie)$

Department of Environmental Engineering and Geodesy, University of Life Sciences in Lublin, Leszczyńskiego Street 7 , 20-069 Lublin, Poland

e-mail: tomasz.zubala@up.lublin.pl

M. Patro

Department of Study Organization, University of Life Sciences in Lublin, Akademicka Street 13, 20-950 Lublin, Poland

e-mail: magdalena.patro@up.lublin.pl high durability and the ability to accumulate in the environment. Therefore, further studies should also take into account monitoring of bottom sediments and areas adjacent to the bypass.

Keywords Road · Rainwater P Pollutants · Reservoirs · Environmental protection

\section{Introduction}

The construction of bypasses in the vicinity of cities is aimed at optimizing and relieving the existing road system, with particular emphasis on transit traffic. The implementation of such investments does not mean, unfortunately, the elimination of threats to the natural environment and people's living conditions. Relieving the transportation route in one place is often associated with the transfer of many negative impacts on other areas. Anthropopression, however, tries to be reduced to the lowest possible level, which is consistent with the concept of sustainable development.

The most important environmental problems associated with the presence of roads with heavy traffic volume include occupancy, destruction and fragmentation of habitats (weakening the ecological cohesion of the area) (O'Brien, 2006), emission of pollutants into the atmosphere (Zhang \& Batterman, 2013), noise emission (Polak et al., 2013), deformation of local hydrological cycle and outflow of polluted rainwater from drained areas (Klimaszewska et al., 2007; McGrane, 2016). Creating sealed surfaces means limiting rainwater 
infiltration, reducing retention and rapid surface runoffs. Disturbances in groundwater recovery processes and water self-purification are observed (Congying, 2012; Geiger \& Dreiseitl, 2001).

According to some authors, pollutants contained in rainwater and snowmelt can pose a serious threat to their natural receivers (e.g. river beds). The quality of rain runoff depends on land development, type of sealed surfaces, volume of traffic, degree of air pollution and weather conditions (Petrucci et al., 2014; Zhang et al., 2014). Given the existence of such a large number of factors, the execution of an accurate forecast of rainwater quality and determining possible threats is very difficult. However, due to the risk of a potentially significant impact on the environment, it is necessary to conduct appropriate observations and develop effective solutions within the scope of rainwater management in urban areas. Research results obtained in various conditions and places around the world should contribute to better understanding of phenomena occurring in drainage systems of road facilities and to determining project recommendations that increase the reliability of specific technologies.

Collection, pretreatment and infiltration of rainwater at the place of its formation are increasingly used. In simple solutions, like permeable surfaces, infiltration basins, settlers and retention ponds, natural selfpurification processes are used (Hossain et al., 2005; Ivanovsky et al., 2018; Zubala \& Patro, 2015). Due to the slowdown of flow, ideal conditions for sedimentation, flotation, dilution and sorption are created. The entry of rainwater into the ground should also be beneficial for the local water balance. Regardless of the method of final management of rainwater runoffs, the precautionary principle and preventing accidental pollution should always be remembered.

The purpose of this study was the assessment of the temporal and spatial variability of rainwater quality collected and pre-treated in reservoirs located next to the new bypass of the Lublin agglomeration (southeastern Poland). These reservoirs are the final stages of the drainage system by which rainwater infiltrates the ground. The levels of water pollution in the early phase of construction of the bypass were determined and the preliminary forecast of possible environmental impacts was made. The analysis involved all rainwater reservoirs as one receiver (common data set) and each of the objects separately as an independent device. The structural differences, the presence or the lack of pre- treatment systems and changes in weather conditions during the research period were taken into account. An attempt was also made to assess the legitimacy of using specific solutions. The collected results should be valuable for scientists working in the field of environmental protection and water management, as well as for designers and users of rainwater management systems.

\section{Material and Methods}

\subsection{The Study Area}

The analysed section of the Lublin bypass was commissioned in October 2014. It bypasses the city from the north and east (Fig. 1). The northern part has two roadways and 6 lanes, and the eastern one has two roadways and 4 lanes in total. The width of the road lane is $3.5 \mathrm{~m}$, and the central reservation is $4-5 \mathrm{~m}$. The width of soft shoulders is in the range of $1.25-2.50 \mathrm{~m}$. The wearing course of the roadway was made of asphalt concrete. According to unpublished data of General Directorate for National Roads and Motorways, the traffic volume in the northern and eastern part of the bypass was similar in the research period, amounting to 12,000 vehicles per day on average. This is a small amount considering that the forecasts show an increase in traffic volume to about 40,000 vehicles a day by 2026 (Rayski et al., 2010).

Along with the bypass, a rainwater harvesting and treatment system containing examined rainwater reservoirs (R1-R5) were commissioned. They are located in the immediate vicinity of the road. Their location is shown in Fig. 1. The bypass drainage system is based on gravity flow. The aim of the reservoirs is to reduce the flow of rainwater (retention) before its channelling to a final receiver and to reduce concentrations of pollutants. Purification of rainwater takes place in the water and ground environment during natural processes, which include sedimentation, flotation, dilution, mixing, sorption, oxygenation, chemical and biological reactions (R1-R5) and filtration (R2-R4).

The area, which the bypass runs through, is characterized by a rolling loess landform with height differences of several dozen meters and large slopes. In some sections, the route runs close to farms, and in the northeastern part, it crosses the periphery of Lublin city. In the final part of the eastern section, it meets a small forest complex - Central European oak-hornbeam (vicinity of reservoir R5) (Fig. 1). The discussed is located 


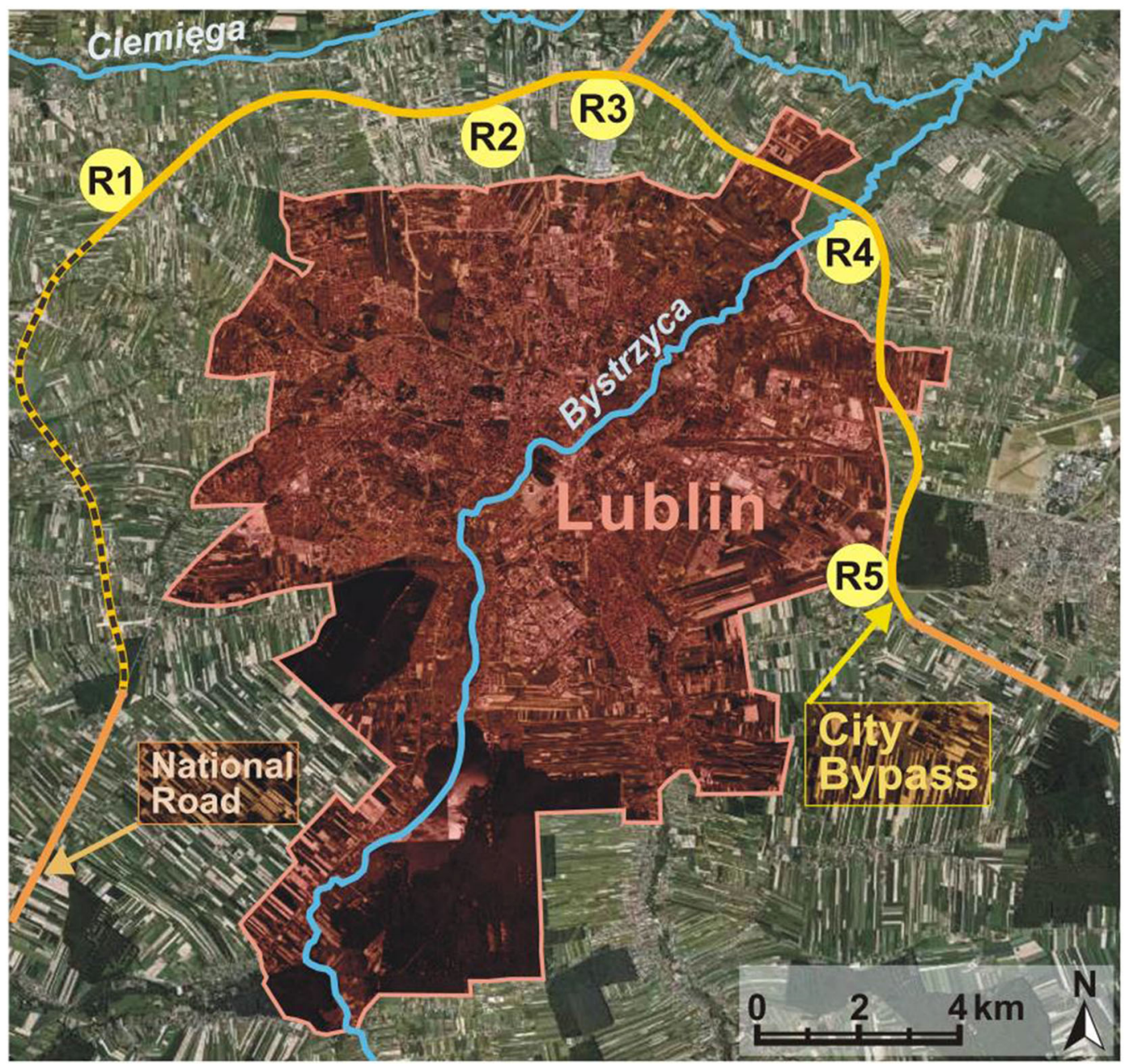

Fig. 1 Location of the bypass and analysed reservoirs of rainwater (R1-R5)

within the protected area of the Main Underground Water Reservoir "Niecka Lubelska". It is one of the largest natural underground water reservoirs in Poland with a high degree of risk (Mikołajków \& Sadurski, 2017). The bypass also runs near valuable natural areas - the Ciemiega river valley (neighbourhood of R1-R3) - and intersects with the Bystrzyca river valley (neighbourhood of R4). Fragments of these lands are under legal protection. In the area of the protected landscape of "Ciemiega Valley" there are peat bogs, riparian forests and marshy meadows (bottom of the valley), thermophilic swards (S-facing slopes) and hornbeam forests (numerous gullies) (Urban, 1995). A special area of habitat protection "Bystrzyca Jakubowicka" (Natura 2000 area) is located just $50 \mathrm{~m}$ from the axis of the bypass. There are lowland habitats and mountain meadows used extensively, habitats of waterlogged meadows and patches of riparian forests (IE, 2019).

\subsection{Climate Conditions}

In the analysed period, annual sums of precipitation were variable and exceeded the average annual precipitation for a multiannual period (Table 1). The year 2016 received higher precipitation than normal with an increase of $100 \mathrm{~mm}$ compared with the average year (1971-2010). The highest monthly sum of precipitation was recorded in July 2016 (138 mm-about 20\% of annual precipitation), with greater than $100 \mathrm{~mm}$ in October as well. In 2017, October was the most abundant in precipitation. Its sum was about twice as high as the average for this month. Similar amounts of precipitation 
were characteristic also for July and September (about $90 \mathrm{~mm}$ ). The driest month in the study period was September 2016 with precipitation of $12 \mathrm{~mm}$. Only $3 \mathrm{~mm}$ higher precipitation was recorded in January 2017. In comparison to the multiannual period (52 $\mathrm{mm}$ ), the differences between minimum and maximum monthly precipitation in a given year have definitely increased (2016, $126 \mathrm{~mm} ; 2017,77 \mathrm{~mm})$. This could have caused a large variation in the size of rainfall runoffs during the research period.

The average annual air temperatures during the study period were higher by $0.7^{\circ} \mathrm{C}(2017)$ and $1.0{ }^{\circ} \mathrm{C}$ (2016) than the multiannual average (Table 1). In 2016-2017, larger differences between minimum and maximum monthly temperatures were also observed. In the analysed period, the coldest month was January with temperatures $-4.2^{\circ} \mathrm{C}(2016)$ and $-5.7^{\circ} \mathrm{C}$ (2017). Negative monthly temperatures were also recorded in December 2016 and February 2017. The highest average monthly air temperatures occurred in summer, which is consistent with values in the multiannual period.

According to Kaszewski (2008), the average annual number of days with snowfall in the research area is 48 . On the other hand, the average annual number of days with snow cover in the Lublin region varies from around 60 to 80 . From field observations conducted in 20162017 , it appears that the total time of lying snow cover during a year did not exceed 30 days.

\subsection{Rainwater Reservoirs}

The distance between fringe reservoirs in a straight line is $16.2 \mathrm{~km}$, and measuring along the road axis $22.9 \mathrm{~km}$ (Fig. 1). Reservoirs 2-4 (R2-R4) have permeable bottoms, while reservoirs 1 and 5 (R1 and R5) are sealed constructions without the possibility of water infiltration into the ground. During maximum flows, excess water overflows from reservoirs and enters the ground. Reservoirs of each type have identical construction. They differ mainly in parameters presented in Table 2. The average catchment area slightly exceeds 8 ha. The analysed catchments have the same types of surface (asphalt roadway, grassy central reservation and soft shoulder).

Sealed reservoirs are earthen structures whose bottom and slopes have been secured with geomembrane (hydroinsulation) laid between protective layers of sand. Inclination of slopes is from 1:1.5 to 1:2. Bottom and slope surfaces (up to the water table) are reinforced with openwork concrete slabs. Under them there is a fine gravel bed (30-cm layer). The slopes above the water table were sodden. Infiltration reservoirs are also earthen structures, whose bottom and slopes are lined with filter geotextile. Geotextile was placed between layers of fine gravel (upper layer, $10 \mathrm{~cm}$; lower layer, $20 \mathrm{~cm}$ ). Side slopes have an incline of 1:2 and are lined with openwork slabs to the start of the water table. Above the slabs, the inner surface of slopes is sown with grass (Fig. 2). Maintenance of reservoirs consists of mowing vegetation, filling soil losses on slopes, maintaining tightness of $\log$ stops and removing sediments. Due to the short time of operation of the analysed facilities, bottom sediments have not been removed so far.

The rainwater supply system for the examined reservoirs includes road inlets with settlement wells, located at the edge of the roadway, lateral sewers, a sealed underground sewer (under the central reservation of the bypass), sealed ditches (only within interchanges), inspection wells and pre-treatment devices (grates, settlers and coalescing separators). Settlers and separators are installed only before infiltration reservoirs (R2-R4). The drainage network consists of stoneware, cast iron or concrete sewer pipes of diameters from 0.2 to $1.2 \mathrm{~m}$.

Table 1 Monthly and annual sums of precipitation and average air temperatures during the study period (2016 and 2017$)$ against the background of average climatic conditions in multiannual period (1971-2010) (CSO, 2017; SP, 2018)

\begin{tabular}{lllllllllllllll}
\hline & Period & I & II & III & IV & V & VI & VII & VIII & IX & X & XI & XII & I-XII \\
\hline Precipitation (mm) & 2016 & 35 & 61 & 59 & 35 & 33 & 52 & 138 & 45 & 12 & 116 & 48 & 64 & 698 \\
& 2017 & 15 & 40 & 34 & 56 & 41 & 30 & 87 & 55 & 88 & 92 & 46 & 29 & 613 \\
& $1971-2010$ & 32 & 30 & 37 & 39 & 63 & 69 & 82 & 69 & 63 & 43 & 38 & 33 & 598 \\
Temperature $\left({ }^{\circ} \mathrm{C}\right)$ & 2016 & -4.2 & 3.0 & 3.5 & 8.9 & 14.4 & 18.3 & 18.9 & 17.8 & 15.2 & 6.7 & 2.2 & -0.2 & 8.7 \\
& 2017 & -5.7 & -1.7 & 5.4 & 7.0 & 13.5 & 17.7 & 18.1 & 19.1 & 13.6 & 8.9 & 3.7 & 1.6 & 8.4 \\
& $1971-2010$ & -3.1 & -2.0 & 2.0 & 8.0 & 13.5 & 16.1 & 18.5 & 17.7 & 13.0 & 7.8 & 3.0 & -1.6 & 7.7 \\
\hline
\end{tabular}


Table 2 Basic parameters of examined reservoirs

\begin{tabular}{lllllll}
\hline Designation & Type & $\begin{array}{l}\text { Bottom surface } \\
\left(\mathrm{m}^{2}\right)\end{array}$ & $\begin{array}{l}\text { Bottom ordinate }(\mathrm{m} \\
\text { a.s.l. })\end{array}$ & $\begin{array}{l}\text { Active/maximum } \\
\text { depth }(\mathrm{m})\end{array}$ & $\begin{array}{l}\text { Active/maximum } \\
\text { capacity }\left(\mathrm{m}^{3}\right)\end{array}$ & $\begin{array}{l}\text { Catchment area } \\
(\text { ha) }\end{array}$ \\
\hline R1 & Sealed & 3800 & 213.10 & $0.90 / 1.40$ & $3610 / 5780$ & 10.7 \\
R2 & Infiltration & 2300 & 204.05 & $0.55 / 2.50$ & $1320 / 6955$ & 5.8 \\
R3 & Infiltration & 2550 & 204.52 & $1.00 / 1.95$ & $2720 / 5755$ & 9.5 \\
R4 & Infiltration & 2620 & 164.80 & $0.75 / 2.50$ & $2090 / 7980$ & 9.4 \\
R5 & Sealed & 1580 & 198.00 & $1.30 / 2.00$ & $2310 / 3840$ & 5.0 \\
Average & - & 2570 & 196.89 & $0.90 / 2.07$ & $2410 / 6062$ & 8.1 \\
R1-R5 & & & & & & \\
\hline
\end{tabular}

\subsection{Analysis of Rainwater Quality}

The research was carried out in 2016-2017. In all reservoirs, samples of water were collected on the same day in a short period of time. Water samples were taken seasonally using a bailer (conditions: 1 meter from the shore, half distance between inflow and outflow, rainless weatherbetween surface runoffs). In the Laboratory of Water and Sewage at the University of Life Sciences in Lublin, electric conductivity (conductometry), $\mathrm{pH}$ (potentiometric), total suspension (dried-weight method), dissolved oxygen $\left(\mathrm{O}_{2}\right), \mathrm{BOD}_{5}$ (dilution method), $\mathrm{COD}$ (bi-chromate method), total nitrogen (TN), ammonium ions $\left(\mathrm{NH}_{4}^{+}\right)$, nitrates $\left(\mathrm{NO}_{3}{ }^{-}\right)$, nitrites $\left(\mathrm{NO}_{2}{ }^{-}\right)$, total phosphorus (TP), phosphates $\left(\mathrm{PO}_{4}{ }^{3-}\right)$, potassium $\left(\mathrm{K}^{+}\right)$and chlorides $\left(\mathrm{Cl}^{-}\right)$ (photometrical) were determined. Chemical components were measured using a Nanocolor VIS (Macherey-Nagel) spectrometer and LF 300 (Slandi) photometer. Physical properties were determined using a multi-parameter device Orion Star A329 (Thermo Fisher Scientific).

In autumn 2016, the content of heavy metals $(\mathrm{Cr}, \mathrm{Zn}$, $\mathrm{Cd}, \mathrm{Cu}, \mathrm{Pb}$ and $\mathrm{Ni}$ ) and polycyclic aromatic hydrocarbons (fluoranthene, benzo(b)fluoranthene, benzo(k)fluoranthene, benzo(a)pyrene, benzo(g,h,i)perylene and indeno(1,2,3cd)pyrene) were measured once in the examined water. These analyses were performed in Central Agroecological Laboratory of the University of Life Sciences in Lublin. The method of mass spectrometry with inductively induced plasma (ICP-MS) (heavy metals) and liquid chromatography (HPLC) with fluorescence detection after liquid-liquid extraction (aromatic hydrocarbons) were applied.

To conduct assessment of the rainwater runoff quality, extreme and average values of analysed indicators
Fig. 2 General view of selected rainwater reservoirs

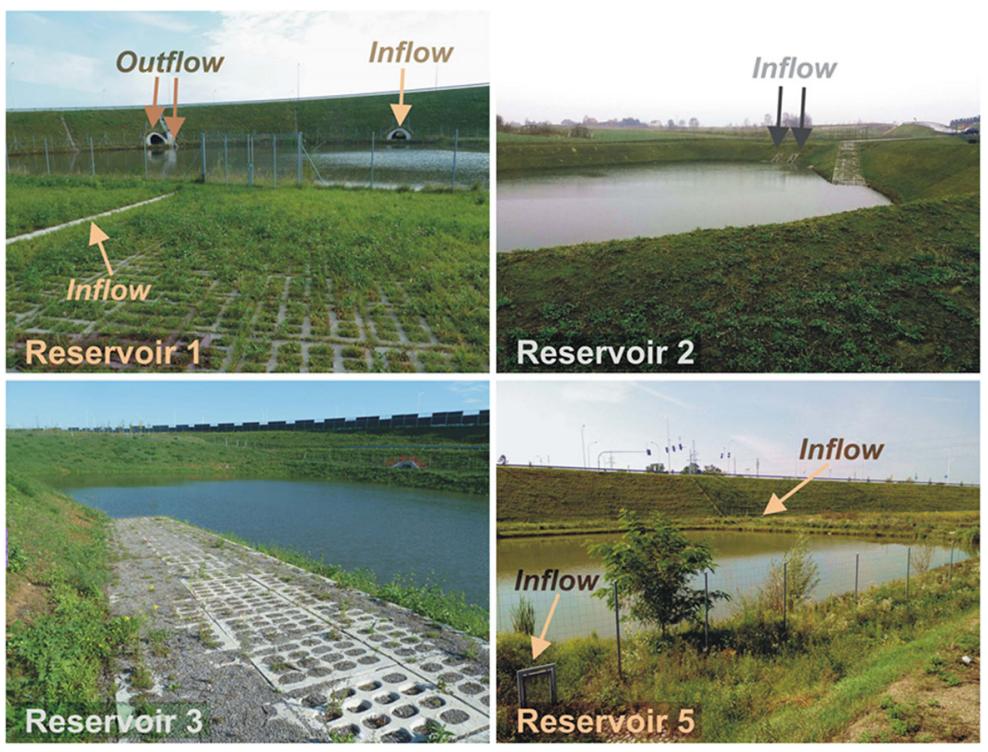


for the reservoirs system and each control point were determined. The statistical variability of obtained results was determined based on values of standard deviation and the coefficient of variation. The Mann-Whitney non-parametric test was used to compare variables of water quality taking account of types of reservoirs (infiltration ones with pre-treatment and sealed ones without pre-treatment). The statistical test also made it possible to determine the significance of differences in water quality between individual years (2016 and 2017) and half-years (spring-summer and autumn-winter). The value of " $n$ " depends on the type of analysis (sets of compared data include 12 to 24 observations, excluding heavy metals and PAH - single measurement). The obtained results were compared with Polish surface water quality standards (quality classes) (Regulation of the Minister of the Environment, 2016) and selected literature data.

\section{Results and Discussion}

\subsection{R1-R5 Reservoir System}

The quality of water collected in the analysed reservoir system is characterized by high variability (Table 3 ). High coefficients of variation, exceeding $100 \%$, include $\mathrm{NO}_{2}^{-}, \mathrm{TP}, \mathrm{PO}_{4}{ }^{3-}, \mathrm{K}^{+}$and $\mathrm{Cl}^{-}(\mathrm{R} 1-\mathrm{R} 5)$. This parameter also achieves a relatively high value in the case of electrolytic conductivity and $\mathrm{NO}_{3}{ }^{-}$(approximately $80 \%$ ). The value of coefficients of variation for the remaining indicators is within $12.6(\mathrm{pH})-70.3 \%$ (suspension). Comparative analysis of individual reservoirs showed extremely high variability in rainwater quality collected in R4. The values of this statistical parameter approach or exceed $100 \%$ in the case of half of the indicators. Among the systems, rainwater in R5 is characterized by the least variation in quality (the highest number of indicators with the lowest variability). Taking into account individual reservoirs, the highest coefficients of variation, amounting to approximately $140 \%$, were recorded in the case of $\mathrm{NO}_{2}{ }^{-}$(R5), TP (R2 and R4) and $\mathrm{Cl}^{-}$(R2). The research carried out in other facilities of the rainwater management in Lublin region also confirms significant variability in the quality of retained water (Zubala, 2013, 2018). This phenomenon results from the existence of a large number of factors determining the extent of pollution of rainfall runoffs. It depends on the usage of drainage area (Peng et al.,
2016; Zhang et al., 2013), the variability of precipitation and thermal conditions in the analysed area (Mangani et al., 2005) (Table 1).

In the majority of measurement dates, rainwater collected in examined reservoirs (system R1-R5) was of unsatisfactory quality (Regulation of the Minister of the Environment, 2016). The indicators lowering the water quality were mainly conductivity, $\mathrm{BOD}_{5}, \mathrm{COD}, \mathrm{NO}_{2}^{-}$, TP and $\mathrm{Cl}^{-}$(Table 3). The maximum value of electric conductivity was $2719.0 \mu \mathrm{S} \cdot \mathrm{cm}^{-1}$ (R2 - March, 2017) with the average for five reservoirs of $1056.2 \mu \mathrm{S} \cdot \mathrm{cm}^{-1}$. The average values of this indicator for individual facilities were within 885.6 (R4)-1285.5 $\mu \mathrm{S} \cdot \mathrm{cm}^{-1}$ (R3). In $35 \%$ of analysed samples, the conductivity value significantly exceeded $1500 \mu \mathrm{S} \cdot \mathrm{cm}^{-1}$. This indicates high water mineralization and its contamination. The increase of conductivity in a given measurement date was always accompanied by an increase of concentration of $\mathrm{Cl}^{-}$. In cases when conductivity exceeded $1500 \mu \mathrm{S} \cdot \mathrm{cm}^{-1}$, the content of $\mathrm{Cl}^{-}$ranged from 480.0 to $1155.0 \mathrm{mg} \cdot \mathrm{dm}^{-3}$. The maximum concentration of $\mathrm{Cl}^{-}$was recorded in the water sample, which was also characterized by the highest conductivity. Discharging rainwater in such condition directly to a natural receiver could increase its salinization (Craig \& Zhu, 2018; Lazur et al., 2020). Salt affects negatively on vegetation not only through splashes (direct proximity of the road) but also through soil solutions (longer distance from the road). This contamination can relocate to long distances with surface runoffs. The high concentration of salt in soil disturbs the process of water and nutrients uptake by plant roots, causing their weakening and death (Mokrani et al., 2020).

In the analysed water, the average $\mathrm{pH}$ value was close to neutral and amounted to 7.4. Only in two samples the level of 9 was exceeded (R5 - summer 2016 and spring 2017). Alkalization of retained rainwater results from the presence of alkaline dust or other specific pollution within the catchment. Due to the very small amount of deposits accumulated in a reservoir in this phase of exploitation, the processes occurring in them should not affect $\mathrm{pH}$ of the water. The concentration of total suspended solids was not too high in the analysed water. Depending on the reservoir, it averaged from 13.9 (R4 and R5) to $27.4 \mathrm{mg} \cdot \mathrm{dm}^{-3}$ (R1). The maximum concentration was recorded in R1 in winter of 2017 (45.8 $\left.\mathrm{mg} \cdot \mathrm{dm}^{-3}\right)$. In the early phase of operation of the drainage system, a large portion of suspensions was retained in settlement wells of road drains. The lack of turbidity 
Table 3 Characteristic values of basic indicators of rainwater quality in the reservoir system (R1-R5) next to the Lublin bypass

\begin{tabular}{|c|c|c|c|c|c|c|}
\hline Variables & Minimal value & Maximum value & Average & Median & Standard deviation & Variation coefficient \\
\hline Conductivity $\left(\mu \mathrm{S} \cdot \mathrm{cm}^{-1}\right)$ & 129.4 & 2719.0 & 1056.2 & 705.9 & 872.8 & 82.6 \\
\hline $\mathrm{pH}$ & 6.4 & 9.7 & 7.4 & 7.1 & 0.9 & 12.6 \\
\hline Suspension $\left(\mathrm{mg} \cdot \mathrm{dm}^{-3}\right)$ & 2.9 & 45.8 & 20.1 & 15.6 & 14.2 & 70.3 \\
\hline $\mathrm{O}_{2}\left(\mathrm{mg} \cdot \mathrm{dm}^{-3}\right)$ & 6.1 & 12.9 & 9.8 & 10.7 & 2.2 & 22.8 \\
\hline $\mathrm{BOD}_{5}\left(\mathrm{mg} \cdot \mathrm{dm}^{-3}\right)$ & 1.7 & 10.5 & 5.8 & 4.9 & 2.4 & 41.3 \\
\hline $\mathrm{COD}_{\mathrm{Cr}}\left(\mathrm{mg} \cdot \mathrm{dm}^{-3}\right)$ & 11.0 & 48.0 & 29.4 & 27.5 & 12.9 & 43.9 \\
\hline $\mathrm{TN}\left(\mathrm{mg} \cdot \mathrm{dm}^{-3}\right)$ & 0.40 & 2.90 & 1.40 & 1.25 & 0.6 & 43.7 \\
\hline $\mathrm{NH}_{4}^{+}\left(\mathrm{mg} \cdot \mathrm{dm}^{-3}\right)$ & 0.01 & 0.32 & 0.15 & 0.15 & 0.1 & 69.3 \\
\hline $\mathrm{NO}_{3}^{-}\left(\mathrm{mg} \cdot \mathrm{dm}^{-3}\right)$ & 0.15 & 3.10 & 0.95 & 0.85 & 0.8 & 83.1 \\
\hline $\mathrm{NO}_{2}^{-}\left(\mathrm{mg} \cdot \mathrm{dm}^{-3}\right)$ & 0.03 & 0.82 & 0.28 & 0.13 & 0.3 & 106.6 \\
\hline $\mathrm{TP}\left(\mathrm{mg} \cdot \mathrm{dm}^{-3}\right)$ & 0.09 & 6.37 & 1.43 & 0.57 & 1.8 & 123.2 \\
\hline $\mathrm{PO}_{4}^{3-}\left(\mathrm{mg} \cdot \mathrm{dm}^{-3}\right)$ & 0.02 & 1.63 & 0.36 & 0.25 & 0.4 & 112.8 \\
\hline $\mathrm{K}^{+}\left(\mathrm{mg} \cdot \mathrm{dm}^{-3}\right)$ & 1.12 & 20.86 & 5.29 & 3.45 & 5.5 & 103.3 \\
\hline $\mathrm{Cl}^{-}\left(\mathrm{mg} \cdot \mathrm{dm}^{-3}\right)$ & 4.5 & 1155.0 & 365.8 & 215.5 & 386.7 & 105.7 \\
\hline
\end{tabular}

characteristic for the inflow of loess dust indicates a good anti-erosion protection of the drained area and sheer reservoirs made of earth. Although some authors point to the affinity of suspensions and nutrients (Vaze \& Chiew, 2004; Wakida et al., 2014), no similar relationships were confirmed in the analysed objects. Other authors' research showed that the hazards from nutrients flowing in rainwater from the road infrastructure are relatively small (Gan et al., 2008). In reservoirs next to the Lublin bypass, this rule applies only to three forms of nitrogen- $\mathrm{TN}, \mathrm{NH}_{4}{ }^{+}$and $\mathrm{NO}_{3}{ }^{-}$. Average concentrations of these variables ranged from $0.15\left(\mathrm{NH}_{4}{ }^{+}\right)$to 1.40 $\mathrm{mg} \cdot \mathrm{dm}^{-3}(\mathrm{TN})$ (Table 3). Other biogenic indicatorsespecially phosphorus - reached alarming values. In one of the measurement dates (mid March 2017), TP concentration was as high as $6.37 \mathrm{mg} \cdot \mathrm{dm}^{-3}$ (R4). With the reservoir volume of $2090 \mathrm{~m}^{3}$, the phosphorus retention was $13.3 \mathrm{~kg}$. In $40 \%$ of water samples, TP significantly exceeded $1.00 \mathrm{mg} \cdot \mathrm{dm}^{-3}$. Average concentrations of $\mathrm{PO}_{4}{ }^{3-}$ in individual reservoirs were within $0.17-0.60$ $\mathrm{mg} \cdot \mathrm{dm}^{-3}$. The maximum value of $1.63 \mathrm{mg} \cdot \mathrm{dm}^{-3}$ was recorded in autumn, 2016 (R2). In all reservoirs, an increase of $\mathrm{NO}_{2}{ }^{-}$concentration was observed in spring of $2017\left(0.72-0.82 \mathrm{mg} \cdot \mathrm{dm}^{-3}\right)$. High concentrations of some nutrients in retained rainwater require great caution in their eventual discharge into natural receivers (risk of eutrophication). It concerns particularly the reservoirs located next to the valuable water and valley ecosystems. Some of them are protected by law.
Concentration of dissolved oxygen $\left(\mathrm{O}_{2}\right)$ in the examined water was maintained at a high level (on average $9.8 \mathrm{mg} \cdot \mathrm{dm}^{-3}$ ), which is very beneficial in the context of self-purification processes (Braskerud et al., 2005; Juang et al., 2008). The highest average value was recorded in $\mathrm{R} 5\left(11.3 \mathrm{mg} \cdot \mathrm{dm}^{-3}\right)$, the lowest in $\mathrm{R} 1$ (8.9 $\left.\mathrm{mg} \cdot \mathrm{dm}^{-3}\right)$. Despite quite good oxygen conditions BOD $_{5}$ and COD reached dangerous levels (Dojlido, 1995). In particular, it applies to the sealed reservoirs without separators, where the average values of these variables were 7.2 and $37.4 \mathrm{mg} \cdot \mathrm{dm}^{-3}$. In $\mathrm{R} 5, \mathrm{BOD}_{5}$ exceeded in all measurement dates $6.5 \mathrm{mg} \cdot \mathrm{dm}^{-3}$ and COD 40 $\mathrm{mg} \cdot \mathrm{dm}^{-3}$. The highest $\mathrm{BOD}_{5}$ was recorded in $\mathrm{R} 2$ in winter of $2017\left(10.5 \mathrm{mg} \cdot \mathrm{dm}^{-3}\right)$. In R2 and R5 also COD reached the maximum level $-48 \mathrm{mg} \cdot \mathrm{dm}^{-3}$.

Due to the difficulty in finding information on similar facilities in the literature (retention reservoirs in the second and third year of operation), the obtained results were collated with the values of pollution in rainwater runoffs and older (stabilised) reservoir systems (Table 4).

\subsection{Exploitation Stage of Reservoirs}

The comparison of the data from 2016 and 2017 showed that the same distributions of values of analysed features exist only in the case of $\mathrm{pH}$, suspension, $\mathrm{O}_{2}$ and $\mathrm{PO}_{4}{ }^{3-}$ (Table 5). Rainwater collected in the system of roadside 
Table 4 Comparison of average values of pollution indicators in rainwater of the R1-R5 system (own studies) with levels of pollution in exemplary rainwater runoffs and roadside rainwater reservoirs (literature data)

\begin{tabular}{|c|c|c|c|c|c|c|}
\hline \multirow[t]{2}{*}{ Variables } & \multicolumn{2}{|l|}{ Reservoirs } & \multicolumn{4}{|l|}{ Runoffs } \\
\hline & Bypass (own studies) & $\begin{array}{l}\text { Highway (Le } \\
\text { Viol et al., 2009) }\end{array}$ & $\begin{array}{l}\text { Highway (Gan } \\
\text { et al., 2008) }\end{array}$ & $\begin{array}{l}\text { Road (Zhang } \\
\text { et al., 2013) }\end{array}$ & $\begin{array}{l}\text { Major road } \\
\text { (Song et al., 2019) }\end{array}$ & $\begin{array}{l}\text { Heavily travelled } \\
\text { catchment (Arora } \\
\text { \& Reddy, 2015) }\end{array}$ \\
\hline Conductivity $\left(\mu \mathrm{S} \cdot \mathrm{cm}^{-1}\right)$ & 1056.2 & 960.0 & 306.0 & - & - & - \\
\hline $\mathrm{pH}$ & 7.4 & 8.2 & 7.2 & 8.2 & - & - \\
\hline Suspension $\left(\mathrm{mg} \cdot \mathrm{dm}^{-3}\right)$ & 20.1 & - & 415.7 & 461.1 & 23.8 & 268.5 \\
\hline $\mathrm{BOD}_{5}\left(\mathrm{mg} \cdot \mathrm{dm}^{-3}\right)$ & 5.8 & - & 13.0 & - & - & 33.5 \\
\hline $\mathrm{COD}\left(\mathrm{mg} \cdot \mathrm{dm}^{-3}\right)$ & 29.4 & - & 308.0 & 163.2 & - & 324.7 \\
\hline $\mathrm{TN}\left(\mathrm{mg} \cdot \mathrm{dm}^{-3}\right)$ & 1.40 & - & 7.32 & 4.74 & 1.14 & - \\
\hline $\mathrm{NH}_{4}^{+}\left(\mathrm{mg} \cdot \mathrm{dm}^{-3}\right)$ & 0.15 & - & - & 2.01 & 0.19 & - \\
\hline $\mathrm{NO}_{3}^{-}\left(\mathrm{mg} \cdot \mathrm{dm}^{-3}\right)$ & 0.95 & 4.23 & 15.44 & 8.85 & 2.30 & - \\
\hline $\mathrm{NO}_{2}^{-}\left(\mathrm{mg} \cdot \mathrm{dm}^{-3}\right)$ & 0.28 & 0.08 & - & - & - & - \\
\hline $\mathrm{TP}\left(\mathrm{mg} \cdot \mathrm{dm}^{-3}\right)$ & 1.43 & - & 0.39 & - & 0.05 & 0.80 \\
\hline $\mathrm{PO}_{4}{ }^{3-}\left(\mathrm{mg} \cdot \mathrm{dm}^{-3}\right)$ & 0.36 & 0.59 & 0.02 & - & 0.03 & - \\
\hline Kjeldahl N $\left(\mathrm{mg} \cdot \mathrm{dm}^{-3}\right)$ & - & - & - & - & - & 10.90 \\
\hline
\end{tabular}

"." no data

reservoirs was much more polluted in the second year of research (third year of facilities operation).

$\mathrm{NH}_{4}{ }^{+}$is the only biogenic indicator whose average concentration was higher in 2016 than in 2017 (the difference was 54.4\%). Much higher conductivity values, $\mathrm{NO}_{3}{ }^{-}, \mathrm{NO}_{2}{ }^{-}, \mathrm{TP}$ and $\mathrm{Cl}^{-}$were observed in the examined water in 2017 (average values $161.0-1003.0 \%)$. In the case of other indicators $\left(\mathrm{BOD}_{5}, \mathrm{COD}, \mathrm{TN}\right.$ and $\left.\mathrm{K}^{+}\right)$, differences were in the range of $51.7-59.3 \%$. In the second year of research, the degree of contamination of conductivity (average $1783.6 \mu \mathrm{S} \cdot \mathrm{cm}^{-1}$ ), $\mathrm{BOD}_{5}$ (average $7.1 \mathrm{mg} \cdot \mathrm{dm}^{-3}$ ), COD (average $35.5 \mathrm{mg} \cdot \mathrm{dm}^{-3}$ ), TP (average $2.61 \mathrm{mg} \mathrm{dm}^{-3}$ ) and $\mathrm{Cl}^{-}\left(659.8 \mathrm{mg} \mathrm{dm}^{-3}\right.$ ) increased dangerously. Major differences in rainwater runoff quality between 2016 and 2017 result from different weather conditions and gradual accumulation of pollutants in new facilities. In 2016, relatively high rainfalls were observed (Table 1), which resulted in larger surface runoffs and caused dilution and leaching of accumulated pollutants (Barbier et al., 2018; Lee et al., 2002). Unfortunately, it is not possible to compare the changes of retained rainwater quality in subsequent years with literature data, because it is difficult to find scientific articles about road drainage systems at such an early stage of their operation.

\subsection{Warm and Cold Half-Years}

A characteristic feature of the temperate climate is the occurrence of four seasons, which can be grouped in a warm half-year (spring-summer) and a cold half-year (autumn-winter). Each of these periods is characterized by different weather conditions (Table 1), which in turn may affect the quality of retained rainwater. In warm half-year, particularly high variability was observed in the case of $\mathrm{NH}_{4}{ }^{+}, \mathrm{NO}_{3}{ }^{-}, \mathrm{PO}_{4}{ }^{3-}, \mathrm{K}^{+}$and $\mathrm{Cl}^{-}$. In cold halfyear, there was large variety in suspension, TP and, like in warm half-year, $\mathrm{PO}_{4}{ }^{3-}, \mathrm{K}^{+}$and $\mathrm{Cl}^{-}$. Based on the assumed confidence level of $0.95(\alpha=0.05)$ and the results of Mann-Whitney test, statistically significant differences between the values of half of the indicators examined in individual half-years were stated (Table 6). It concerns primarily conductivity, $\mathrm{O}_{2}, \mathrm{COD}, \mathrm{NH}_{4}{ }^{+}$and $\mathrm{NO}_{2}{ }^{-}$. In addition, the different distribution of $\mathrm{NO}_{3}{ }^{-}$and $\mathrm{Cl}^{-}$concentrations was found in the statistical test for $\alpha=0.10$.

In the analysed water, the highest electrolytic conductivity was observed in cold half-year period (especially in winter). The average value reached a high level-1293.5 $\mu \mathrm{S} \cdot \mathrm{cm}^{-1}$ (maximum $2719.0 \mu \mathrm{S} \cdot \mathrm{cm}^{-1}$ in R2). In warm half-year period, conductivity was $57.9 \%$ lower and only in $20 \%$ of samples exceeded 1000.0 $\mu \mathrm{S} \cdot \mathrm{cm}^{-1}$ (R3 and R5). High conductivity in a cold 
Table 5 Characteristic values of basic indicators of rainwater quality in reservoirs next to the bypass in 2016 (1) $(n=20)$ and 2017 (2) $(n=$ 20) (statistical significance of differences in quality variables was determined for the level $\alpha=0.05$ - Mann-Whitney test)

\begin{tabular}{|c|c|c|c|c|c|c|c|c|}
\hline Variables & Year & $\begin{array}{l}\text { Minimal } \\
\text { value }\end{array}$ & $\begin{array}{l}\text { Maximum } \\
\text { value }\end{array}$ & Average & $\begin{array}{l}\text { Percentage } \\
\text { difference }\end{array}$ & $\begin{array}{c}\text { Standard } \\
\text { deviation }\end{array}$ & $\begin{array}{l}\text { Variation } \\
\text { coefficient }\end{array}$ & $\begin{array}{l}\text { Important } \\
\text { difference }\end{array}$ \\
\hline $\begin{array}{l}\text { Conductivity } \\
\left(\mu \mathrm{S} \cdot \mathrm{cm}^{-1}\right)\end{array}$ & $\begin{array}{l}1 \\
2\end{array}$ & $\begin{array}{l}129.4 \\
913.0\end{array}$ & $\begin{array}{l}498.7 \\
2719.0\end{array}$ & $\begin{array}{l}328.9 \\
1783.6\end{array}$ & +442.4 & $\begin{array}{l}145.6 \\
641.4\end{array}$ & $\begin{array}{l}44.3 \\
36.0\end{array}$ & + \\
\hline $\mathrm{pH}$ & $\begin{array}{l}1 \\
2\end{array}$ & $\begin{array}{l}6.4 \\
6.7\end{array}$ & $\begin{array}{l}9.2 \\
9.7\end{array}$ & $\begin{array}{l}7.3 \\
7.5\end{array}$ & +2.5 & $\begin{array}{l}0.9 \\
1.0\end{array}$ & $\begin{array}{l}12.1 \\
13.6\end{array}$ & - \\
\hline $\begin{array}{l}\text { Suspension } \\
\qquad\left(\mathrm{mg} \cdot \mathrm{dm}^{-3}\right)\end{array}$ & $\begin{array}{l}1 \\
2\end{array}$ & $\begin{array}{l}6.1 \\
2.9\end{array}$ & $\begin{array}{l}41.7 \\
45.8\end{array}$ & $\begin{array}{l}24.4 \\
15.9\end{array}$ & -35.1 & $\begin{array}{l}12.0 \\
15.4\end{array}$ & $\begin{array}{l}49.2 \\
97.4\end{array}$ & - \\
\hline $\begin{array}{l}\mathrm{O}_{2} \\
\left(\mathrm{mg} \cdot \mathrm{dm}^{-3}\right)\end{array}$ & $\begin{array}{l}1 \\
2\end{array}$ & $\begin{array}{l}6.1 \\
7.4\end{array}$ & $\begin{array}{l}12.1 \\
12.9\end{array}$ & $\begin{array}{l}9.3 \\
10.4\end{array}$ & +12.0 & $\begin{array}{l}2.3 \\
2.2\end{array}$ & $\begin{array}{l}24.6 \\
21.0\end{array}$ & - \\
\hline $\begin{array}{l}\mathrm{BOD}_{5} \\
\left(\mathrm{mg} \cdot \mathrm{dm}^{-3}\right)\end{array}$ & $\begin{array}{l}1 \\
2\end{array}$ & $\begin{array}{l}1.7 \\
3.4\end{array}$ & $\begin{array}{l}7.5 \\
10.5\end{array}$ & $\begin{array}{l}4.5 \\
7.1\end{array}$ & +55.5 & $\begin{array}{l}1.7 \\
2.4\end{array}$ & $\begin{array}{l}36.7 \\
34.1\end{array}$ & + \\
\hline $\begin{array}{l}\mathrm{COD}_{\mathrm{Cr}} \\
\left(\mathrm{mg} \cdot \mathrm{dm}^{-3}\right)\end{array}$ & $\begin{array}{l}1 \\
2\end{array}$ & $\begin{array}{l}11.0 \\
18.0\end{array}$ & $\begin{array}{l}48.0 \\
48.0\end{array}$ & $\begin{array}{l}23.3 \\
35.5\end{array}$ & +52.4 & $\begin{array}{l}12.8 \\
10.3\end{array}$ & $\begin{array}{l}54.7 \\
29.0\end{array}$ & + \\
\hline $\begin{array}{l}\mathrm{TN} \\
\left(\mathrm{mg} \cdot \mathrm{dm}^{-3}\right)\end{array}$ & $\begin{array}{l}1 \\
2\end{array}$ & $\begin{array}{l}0.40 \\
1.00\end{array}$ & $\begin{array}{l}1.80 \\
2.90\end{array}$ & $\begin{array}{l}1.08 \\
1.72\end{array}$ & +59.3 & $\begin{array}{l}0.4 \\
0.6\end{array}$ & $\begin{array}{l}34.9 \\
37.8\end{array}$ & + \\
\hline $\begin{array}{l}\mathrm{NH}_{4}^{+} \\
\left(\mathrm{mg} \cdot \mathrm{dm}^{-3}\right)\end{array}$ & $\begin{array}{l}1 \\
2\end{array}$ & $\begin{array}{l}0.01 \\
0.01\end{array}$ & $\begin{array}{l}0.32 \\
0.22\end{array}$ & $\begin{array}{l}0.20 \\
0.09\end{array}$ & -54.4 & $\begin{array}{l}0.1 \\
0.1\end{array}$ & $\begin{array}{l}47.0 \\
85.4\end{array}$ & + \\
\hline $\begin{array}{l}\mathrm{NO}_{3}^{-} \\
\left(\mathrm{mg} \cdot \mathrm{dm}^{-3}\right)\end{array}$ & $\begin{array}{l}1 \\
2\end{array}$ & $\begin{array}{l}0.15 \\
0.44\end{array}$ & $\begin{array}{l}1.07 \\
3.10\end{array}$ & $\begin{array}{l}0.53 \\
1.37\end{array}$ & +161.0 & $\begin{array}{l}0.3 \\
0.9\end{array}$ & $\begin{array}{l}62.6 \\
65.5\end{array}$ & + \\
\hline $\begin{array}{l}\mathrm{NO}_{2}^{-} \\
\left(\mathrm{mg} \cdot \mathrm{dm}^{-3}\right)\end{array}$ & $\begin{array}{l}1 \\
2\end{array}$ & $\begin{array}{l}0.06 \\
0.03\end{array}$ & $\begin{array}{l}0.16 \\
0.82\end{array}$ & $\begin{array}{l}0.11 \\
0.44\end{array}$ & $+290,3$ & $\begin{array}{l}0.03 \\
0.4\end{array}$ & $\begin{array}{l}28.3 \\
79.7\end{array}$ & + \\
\hline $\begin{array}{l}\mathrm{TP} \\
\left(\mathrm{mg} \cdot \mathrm{dm}^{-3}\right)\end{array}$ & $\begin{array}{l}1 \\
2\end{array}$ & $\begin{array}{l}0.09 \\
0.53\end{array}$ & $\begin{array}{l}0.61 \\
6.37\end{array}$ & $\begin{array}{l}0.24 \\
2.61\end{array}$ & +1003.0 & $\begin{array}{l}0.2 \\
1.8\end{array}$ & $\begin{array}{l}71.4 \\
69.9\end{array}$ & + \\
\hline $\begin{array}{l}\mathrm{PO}_{4}^{3-} \\
\left(\mathrm{mg} \cdot \mathrm{dm}^{-3}\right)\end{array}$ & $\begin{array}{l}1 \\
2\end{array}$ & $\begin{array}{l}0.02 \\
0.04\end{array}$ & $\begin{array}{l}1.63 \\
1.10\end{array}$ & $\begin{array}{l}0.33 \\
0.38\end{array}$ & +14.1 & $\begin{array}{l}0.5 \\
0.3\end{array}$ & $\begin{array}{l}145.9 \\
85.0\end{array}$ & - \\
\hline $\begin{array}{l}\mathrm{K}^{+} \\
\left(\mathrm{mg} \cdot \mathrm{dm}^{-3}\right)\end{array}$ & $\begin{array}{l}1 \\
2\end{array}$ & $\begin{array}{l}1.12 \\
1.65\end{array}$ & $\begin{array}{l}15.10 \\
20.86\end{array}$ & $\begin{array}{l}4.21 \\
6.38\end{array}$ & +51.7 & $\begin{array}{l}4.9 \\
6.0\end{array}$ & $\begin{array}{l}117.6 \\
94.1\end{array}$ & + \\
\hline $\begin{array}{l}\mathrm{Cl}^{-} \\
\left(\mathrm{mg} \cdot \mathrm{dm}^{-3}\right)\end{array}$ & $\begin{array}{l}1 \\
2\end{array}$ & $\begin{array}{l}4.5 \\
203.0\end{array}$ & $\begin{array}{l}274.0 \\
1155.0\end{array}$ & $\begin{array}{l}71.7 \\
659.8\end{array}$ & +820.1 & $\begin{array}{l}81.3 \\
341.9\end{array}$ & $\begin{array}{l}113.4 \\
51.8\end{array}$ & + \\
\hline
\end{tabular}

half-year is associated with thaw runoffs, carrying with them high loads of pollutants. The presence of snow cover for a longer period of time conduces to the gradual accumulation of subsequent portions of contaminants, including substances to reduce road slipperiness (Kuoppamäki et al., 2014; Ociepa et al., 2015). In December 2016 and January and February 2017, relatively low air temperatures were recorded (Table 1) and road icing appeared. As a result, it was necessary to use salt $(\mathrm{NaCl})$ more often to ensure traffic safety. In winter, the highest content of $\mathrm{Cl}^{-}$in water sample was observed. The maximum level of $\mathrm{Cl}^{-}$was recorded in $\mathrm{R} 2$ $1155.0 \mathrm{mg} \cdot \mathrm{dm}^{-3}$. Taking into account the active capacity of this reservoir, retention of $\mathrm{Cl}^{-}$ amounted to $1524.6 \mathrm{~kg}$. The average concentration of $\mathrm{Cl}^{-}$in $\mathrm{R} 1-\mathrm{R} 5$ reservoirs system was $56.4 \%$ higher in a cold half-year than in a warm one.
In a cold half-year, favourable oxygen conditions in water were observed. Average oxygen saturation in this period was almost $50 \%$ higher in comparison with a warm half-year and amounted to $11.6 \mathrm{mg} \cdot \mathrm{dm}^{-3}$ (in all dates the value of $\mathrm{O}_{2}$ exceeded $10.5 \mathrm{mg} \cdot \mathrm{dm}^{-3}$ ). One of the reasons for this phenomenon could be significant temperature drops in autumn and winter, which favours the increased natural solubility of $\mathrm{O}_{2}$ in water (Dojlido, 1995). The lowest concentration of $\mathrm{O}_{2}$ occurred in summer of 2016 - it reached $6.1 \mathrm{mg} \cdot \mathrm{dm}^{-3}$. In warm halfyear, there was also a higher average value of COD (difference 27.1\%). However, no significant difference was found in $\mathrm{BOD}_{5}$ values between the analysed halfyears. In the case of deterioration of aerobic conditions in warm season, the necessity of artificial oxygenation using mechanical or chemical methods should be taken into consideration (Imhoff \& Imhoff, 2006). 
In rainwater runoff in cold half-year, higher average concentrations of $\mathrm{NH}_{4}{ }^{+}$and $\mathrm{NO}_{3}{ }^{-}$were observed than in water in warm half-year (Table 6). The differences were 75.0 and $68.0 \%$ consecutively. On the other hand, in warm half-year, there was a significantly higher $\mathrm{NO}_{2}{ }^{-}$ pollution $(75.8 \%)$. The average values of TN and $\mathrm{PO}_{4}{ }^{3-}$ were at a similar level in both half-years. Among the mentioned nutrients, the biggest threat to natural water receivers (eutrophication) were $\mathrm{NO}_{2}^{-}$(warm half-year), $\mathrm{TP}$ and $\mathrm{PO}_{4}{ }^{3-}$ (both half-years).

\subsection{Types of Reservoirs-Pre-treatment}

Comparing reservoir systems without pre-treatment and with pre-treatment (separator, settler), there are not as many significant differences in rainwater runoff quality as in the case of qualitative differences between successive years and half-years. In reservoirs without pretreatment, higher values of $\mathrm{BOD}_{5}, \mathrm{COD}(\alpha=0.05), \mathrm{TN}$ and $\mathrm{K}^{+}(\alpha=0.10)$ were recorded than in reservoirs preceded by pre-treatment devices. Differences in average quantities of these variables were 32.2-66.9\% (Table 7).

The presence of a separator and a settler before a rainwater reservoir probably contributes to the reduction in pollutants responsible for biochemical and chemical oxygen demand. High values of $\mathrm{BOD}_{5}$ and $\mathrm{COD}$ occurred in reservoirs without pre-treatment in winter and spring of 2017. They amounted on average to 8.5 and $42.0 \mathrm{mg} \cdot \mathrm{dm}^{-3}$. In the same period, the discussed indicators reached the level of 6.1 and $31.0 \mathrm{mg} \cdot \mathrm{dm}^{-3}$ in reservoirs with separators and settlers. The statistical test showed the existence of similar distributions of suspension content in both reservoir systems. The obtained results indicate that separators and settlers do not guarantee a significantly lower content of suspended substances in the collected water compared with systems without pre-treatment. Another reason is the presence of an internal source of these pollutions in some reservoirs. The increase in the content of total suspension follows behind pre-treatment devices - e.g. as a result of intensive phytoplankton development (in warm half-year there were signs of bloom) (Sarkar et al., 2014). During the research period, no signs of erosive damage in the reservoirs were found despite the high inclination of their slopes. Well-developed grassy vegetation effectively protects the surface affected by water. Separators and settlers do not ensure a significantly lower chloride level in retained rainwater either. The average concentration of $\mathrm{Cl}^{-}$was even higher by $20.5 \%$ in reservoirs with pre-treatment compared with reservoirs without separators and settlers. With the exception of TN, no significant differences in the concentration of nutrients in both reservoir systems were found during the study.

In the reservoirs with pre-treatment, a significant increase in the average values of conductivity, chlorides and TP was noted in the second year of research $(n=12$, $\alpha=0.05$ ). The differences between the analysed years amounted to $493.8,782.9$ and $1443.3 \%$, respectively. In 2017, in reservoirs without settlers and separators, the values of these indicators were higher by $377.9,895.0$ and $538.6 \%$ compared with 2016. Despite a larger percentage difference, the average chloride concentration in reservoirs without pre-treatment was lower by 113.0 $\mathrm{mg} \cdot \mathrm{dm}^{-3}$ in 2017 compared with reservoirs with pretreatment. In both types of reservoirs, significantly higher $\mathrm{O}_{2}$ concentration was recorded in cool half-years. The differences between half-years were $36.4 \%$ (reservoirs without preliminary treatment) and $53.3 \%$ (reservoirs with preliminary treatment). In the rainwater collected in reservoirs with pre-treatment, $\mathrm{NO}_{3}{ }^{-}(160.3 \%)$ and $\mathrm{NO}_{2}^{-}(73.1 \%)$ content also increased in cool halfyears.

\subsection{Heavy Metals and Polycyclic Aromatic Hydrocarbons}

Single determination of heavy metals in rainwater of the examined reservoirs showed at most a moderate load of this type of pollutants. Concentrations of $\mathrm{Cd}$ and $\mathrm{Pb}$ did not exceed the limit of quantification, amounting to 0.086 and $0.132 \mu \mathrm{g} \cdot \mathrm{dm}^{-3}$ successively (Table 8 ). In all measuring points, $\mathrm{Zn}$ achieved the highest values. The average content of this metal in water was $7.74 \mu \mathrm{g} \cdot \mathrm{dm}^{-3}$ with the maximum of $10.30 \mu \mathrm{g} \cdot \mathrm{dm}^{-3}$ in $\mathrm{R} 4$. The average concentrations of $\mathrm{Cr}, \mathrm{Cu}$ and $\mathrm{Ni}$ were in the range of 2.00-2.80 $\mu \mathrm{g} \cdot \mathrm{dm}^{-3}$. Among detected metals, the highest coefficient of variation was found in $\mathrm{Ni}(59.4 \%)$ and the lowest in $\mathrm{Cr}(18.3 \%)$.

The average concentrations of $\mathrm{Zn}, \mathrm{Cu}$ and $\mathrm{Pb}$ in the examined water were usually many times smaller compared with runoffs from routes described in the literature (especially the first runoff phase) (Angrill et al., 2017; Zhang et al., 2013). In rainwater outflows from a car park, concentrations of metals can be as high as $70(\mathrm{Cr})$ $900(\mathrm{Zn}$ and $\mathrm{Ni}$ ) times higher than in retained water in the reservoirs next to the Lublin bypass (Newman et al., 2013). It should be remembered that the analysed system of rainwater management functions only a few 
years and heavy metal compounds are characterized by high durability and cumulative capacity in the environment (Kabata-Pendias \& Mukherjee, 2007; Zubala et al., 2017). Gan et al. (2008) also showed great pollution of topsoil next to motorways, accompanied by a significant increase in $\mathrm{pH}$. For this reason, cyclical monitoring observations should cover not only water but also bottom sediments and areas adjacent to roads.

The particularly harmful pollutants include also polycyclic aromatic hydrocarbons (PAHs). In examined water, its contents were within 0.004 (benzo(k)fluoranthene)$0.037 \mu \mathrm{g} \cdot \mathrm{dm}^{-3}$ (fluoranthene). The variability of concentration remained on an average level and was similar for most hydrocarbons. The coefficient of variation ranged from 34.8 (benzo( $\mathrm{g}, \mathrm{h}, \mathrm{i})$ perylene) to $50.5 \%$

Table 6 Characteristic values of basic indicators of rainwater quality in reservoirs next to the bypass in the warm (1) $(n=20)$ and cold (2) half-year period $(n=20)$ (statistical significance of (benzo(a)pyrene) (Table 8). The highest degree of contamination characterized water in R1 with the sum of PAHs amounting to $0.146 \mu \mathrm{g} \cdot \mathrm{dm}^{-3}$, and the smallest R5, in which only fluoranthene $\left(0.027 \mu \mathrm{g} \cdot \mathrm{dm}^{-3}\right)$ was detected. In both reservoirs there is no pre-treatment using separators and settlers. The highest percentages in rainwater pollution had fluoranthene and benzo(g,h,i)perylene. They reached approximately $50 \%$. In reservoirs preceded by separators and settlers, higher contents of four out of six analyzed hydrocarbons were found, compared with reservoirs without pre-treatment.

It is difficult to refer the obtained results to few data in the literature, as each scientific paper included different types or amounts of PAHs. They are often presented as general hydrocarbons bound to solid particles. It was

differences in quality variables were determined for the level $\alpha=0.05-$ Mann-Whitney test)

\begin{tabular}{|c|c|c|c|c|c|c|c|c|}
\hline Variables & $\begin{array}{l}\text { Half- } \\
\text { year }\end{array}$ & $\begin{array}{l}\text { Minimal } \\
\text { value }\end{array}$ & $\begin{array}{l}\text { Maximum } \\
\text { value }\end{array}$ & Average & $\begin{array}{l}\text { Percentage } \\
\text { difference }\end{array}$ & $\begin{array}{l}\text { Standard } \\
\text { deviation }\end{array}$ & $\begin{array}{l}\text { Variation } \\
\text { coefficient }\end{array}$ & $\begin{array}{l}\text { Important } \\
\text { difference }\end{array}$ \\
\hline $\begin{array}{l}\text { Conductivity } \\
\qquad\left(\mu \mathrm{S} \cdot \mathrm{cm}^{-1}\right)\end{array}$ & $\begin{array}{l}1 \\
2\end{array}$ & $\begin{array}{l}129.4 \\
147.8\end{array}$ & $\begin{array}{l}1956.0 \\
2719.0\end{array}$ & $\begin{array}{l}819.0 \\
1293.5\end{array}$ & +57.9 & $\begin{array}{l}634.7 \\
1039.4\end{array}$ & $\begin{array}{l}77.5 \\
80.4\end{array}$ & + \\
\hline $\mathrm{pH}$ & $\begin{array}{l}1 \\
2\end{array}$ & $\begin{array}{l}6.5 \\
6.4\end{array}$ & $\begin{array}{l}9.7 \\
8.9\end{array}$ & $\begin{array}{l}7.7 \\
7.1\end{array}$ & -7.5 & $\begin{array}{l}1.0 \\
0.8\end{array}$ & $\begin{array}{l}13.4 \\
10.9\end{array}$ & - \\
\hline $\begin{array}{l}\text { Suspension } \\
\qquad\left(\mathrm{mg} \cdot \mathrm{dm}^{-3}\right)\end{array}$ & $\begin{array}{l}1 \\
2\end{array}$ & $\begin{array}{l}10.3 \\
2.9\end{array}$ & $\begin{array}{l}41.3 \\
45.8\end{array}$ & $\begin{array}{l}24.9 \\
15.4\end{array}$ & -38.2 & $\begin{array}{l}11.0 \\
15.9\end{array}$ & $\begin{array}{l}44.1 \\
103.3\end{array}$ & - \\
\hline $\begin{array}{l}\mathrm{O}_{2} \\
\left(\mathrm{mg} \cdot \mathrm{dm}^{-3}\right)\end{array}$ & $\begin{array}{l}1 \\
2\end{array}$ & $\begin{array}{l}6.1 \\
10.7\end{array}$ & $\begin{array}{l}11.5 \\
12.9\end{array}$ & $\begin{array}{l}8.0 \\
11.6\end{array}$ & +46.0 & $\begin{array}{l}1.5 \\
0.9\end{array}$ & $\begin{array}{l}19.4 \\
7.3\end{array}$ & + \\
\hline $\begin{array}{l}\mathrm{BOD}_{5} \\
\left(\mathrm{mg} \cdot \mathrm{dm}^{-3}\right)\end{array}$ & $\begin{array}{l}1 \\
2\end{array}$ & $\begin{array}{l}3.0 \\
1.7\end{array}$ & $\begin{array}{l}9.5 \\
10.5\end{array}$ & $\begin{array}{l}5.4 \\
6.2\end{array}$ & +15.6 & $\begin{array}{l}2.0 \\
2.8\end{array}$ & $\begin{array}{l}37.7 \\
44.3\end{array}$ & - \\
\hline $\begin{array}{l}\mathrm{COD}_{\mathrm{Cr}} \\
\left(\mathrm{mg} \cdot \mathrm{dm}^{-3}\right)\end{array}$ & $\begin{array}{l}1 \\
2\end{array}$ & $\begin{array}{l}17.0 \\
11.0\end{array}$ & $\begin{array}{l}48.0 \\
43.0\end{array}$ & $\begin{array}{l}34.0 \\
24.8\end{array}$ & -27.1 & $\begin{array}{l}12.0 \\
12.6\end{array}$ & $\begin{array}{l}35.3 \\
51.0\end{array}$ & + \\
\hline $\begin{array}{l}\mathrm{TN} \\
\left(\mathrm{mg} \cdot \mathrm{dm}^{-3}\right)\end{array}$ & $\begin{array}{l}1 \\
2\end{array}$ & $\begin{array}{l}0.40 \\
0.70\end{array}$ & $\begin{array}{l}2.90 \\
1.80\end{array}$ & $\begin{array}{l}1.47 \\
1.33\end{array}$ & -9.5 & $\begin{array}{l}0.8 \\
0.4\end{array}$ & $\begin{array}{l}55.1 \\
26.5\end{array}$ & - \\
\hline $\begin{array}{l}\mathrm{NH}_{4}^{+} \\
\left(\mathrm{mg} \cdot \mathrm{dm}^{-3}\right)\end{array}$ & $\begin{array}{l}1 \\
2\end{array}$ & $\begin{array}{l}0.01 \\
0.10\end{array}$ & $\begin{array}{l}0.31 \\
0.32\end{array}$ & $\begin{array}{l}0.11 \\
0.19\end{array}$ & +75.0 & $\begin{array}{l}0.1 \\
0.1\end{array}$ & $\begin{array}{l}108.5 \\
37.4\end{array}$ & + \\
\hline $\begin{array}{l}\mathrm{NO}_{3}^{-} \\
\left(\mathrm{mg} \cdot \mathrm{dm}^{-3}\right)\end{array}$ & $\begin{array}{l}1 \\
2\end{array}$ & $\begin{array}{l}0.15 \\
0.39\end{array}$ & $\begin{array}{l}2.65 \\
3.10\end{array}$ & $\begin{array}{l}0.71 \\
1.19\end{array}$ & +68.0 & $\begin{array}{l}0.7 \\
0.8\end{array}$ & $\begin{array}{l}105.1 \\
66.8\end{array}$ & $\overline{(}(+\alpha=0.10)$ \\
\hline $\begin{array}{l}\mathrm{NO}_{2}^{-} \\
\left(\mathrm{mg} \cdot \mathrm{dm}^{-3}\right)\end{array}$ & $\begin{array}{l}1 \\
2\end{array}$ & $\begin{array}{l}0.08 \\
0.03\end{array}$ & $\begin{array}{l}0.82 \\
0.23\end{array}$ & $\begin{array}{l}0.45 \\
0.11\end{array}$ & -75.8 & $\begin{array}{l}0.3 \\
0.1\end{array}$ & $\begin{array}{l}76.9 \\
52.5\end{array}$ & + \\
\hline $\begin{array}{l}\text { TP } \\
\left(\mathrm{mg} \cdot \mathrm{dm}^{-3}\right)\end{array}$ & $\begin{array}{l}1 \\
2\end{array}$ & $\begin{array}{l}0.09 \\
0.14\end{array}$ & $\begin{array}{l}2.02 \\
6.37\end{array}$ & $\begin{array}{l}0.90 \\
1.95\end{array}$ & +116.8 & $\begin{array}{l}0.8 \\
2.3\end{array}$ & $\begin{array}{l}89.2 \\
117.4\end{array}$ & - \\
\hline $\begin{array}{l}\mathrm{PO}_{4}^{3-} \\
\left(\mathrm{mg} \cdot \mathrm{dm}^{-3}\right)\end{array}$ & $\begin{array}{l}1 \\
2\end{array}$ & $\begin{array}{l}0.02 \\
0.04\end{array}$ & $\begin{array}{l}1.10 \\
1.63\end{array}$ & $\begin{array}{l}0.35 \\
0.37\end{array}$ & +6.6 & $\begin{array}{l}0.3 \\
0.5\end{array}$ & $\begin{array}{l}99.4 \\
128.5\end{array}$ & - \\
\hline $\begin{array}{l}\mathrm{K}^{+} \\
\left(\mathrm{mg} \cdot \mathrm{dm}^{-3}\right)\end{array}$ & $\begin{array}{l}1 \\
2\end{array}$ & $\begin{array}{l}1.16 \\
1.12\end{array}$ & $\begin{array}{l}15.10 \\
20.86\end{array}$ & $\begin{array}{l}4.52 \\
6.07\end{array}$ & +34.4 & $\begin{array}{l}5.0 \\
6.1\end{array}$ & $\begin{array}{l}110.4 \\
100.1\end{array}$ & - \\
\hline $\begin{array}{l}\mathrm{Cl}^{-} \\
\left(\mathrm{mg} \cdot \mathrm{dm}^{-3}\right)\end{array}$ & $\begin{array}{l}1 \\
2\end{array}$ & $\begin{array}{l}5.6 \\
4.5\end{array}$ & $\begin{array}{l}1000.0 \\
1155.0\end{array}$ & $\begin{array}{l}285.3 \\
446.2\end{array}$ & +56.4 & $\begin{array}{l}329.2 \\
439.2\end{array}$ & $\begin{array}{l}115.4 \\
98.4\end{array}$ & $(+\alpha=0.10)$ \\
\hline
\end{tabular}


Table 7 Characteristic values of basic indicators of rainwater quality in reservoirs without pre-treatment $(1)(n=16)$ and with pre-treatment (2) $(n=24)$ (statistical significance of differences in quality variables was determined for the level $\alpha=0.05-$ Mann-Whitney test)

\begin{tabular}{|c|c|c|c|c|c|c|c|c|}
\hline Variables & $\begin{array}{l}\text { Res. } \\
\text { type }\end{array}$ & $\begin{array}{l}\text { Minimal } \\
\text { value }\end{array}$ & $\begin{array}{l}\text { Maximum } \\
\text { value }\end{array}$ & Average & $\begin{array}{l}\text { Percentage } \\
\text { difference }\end{array}$ & $\begin{array}{l}\text { Standard } \\
\text { deviation }\end{array}$ & $\begin{array}{l}\text { Variation } \\
\text { coefficient }\end{array}$ & $\begin{array}{l}\text { Important } \\
\text { difference }\end{array}$ \\
\hline $\begin{array}{l}\text { Conductivity } \\
\qquad\left(\mu \mathrm{S} \cdot \mathrm{cm}^{-1}\right)\end{array}$ & $\begin{array}{l}1 \\
2\end{array}$ & $\begin{array}{l}129.4 \\
143.1\end{array}$ & $\begin{array}{l}2301.0 \\
2719.0\end{array}$ & $\begin{array}{l}1054.2 \\
1057.6\end{array}$ & +0.3 & $\begin{array}{l}828.6 \\
937.5\end{array}$ & $\begin{array}{l}78.6 \\
88.6\end{array}$ & - \\
\hline $\mathrm{pH}$ & $\begin{array}{l}1 \\
2\end{array}$ & $\begin{array}{l}6.5 \\
6.4\end{array}$ & $\begin{array}{l}9.7 \\
8.9\end{array}$ & $\begin{array}{l}7.4 \\
7.3\end{array}$ & -1.1 & $\begin{array}{l}1.3 \\
0.7\end{array}$ & $\begin{array}{l}17.2 \\
9.2\end{array}$ & - \\
\hline $\begin{array}{l}\text { Suspension } \\
\qquad\left(\mathrm{mg} \cdot \mathrm{dm}^{-3}\right)\end{array}$ & $\begin{array}{l}1 \\
2\end{array}$ & $\begin{array}{l}3.7 \\
2.9\end{array}$ & $\begin{array}{l}45.8 \\
41.7\end{array}$ & $\begin{array}{l}20.6 \\
19.8\end{array}$ & -4.0 & $\begin{array}{l}13.1 \\
15.4\end{array}$ & $\begin{array}{l}63.4 \\
77.8\end{array}$ & - \\
\hline $\begin{array}{l}\mathrm{O}_{2} \\
\left(\mathrm{mg} \cdot \mathrm{dm}^{-3}\right)\end{array}$ & $\begin{array}{l}1 \\
2\end{array}$ & $\begin{array}{l}6.1 \\
6.3\end{array}$ & $\begin{array}{l}12.9 \\
12.8\end{array}$ & $\begin{array}{l}10.1 \\
9.6\end{array}$ & -4.5 & $\begin{array}{l}2.3 \\
2.3\end{array}$ & $\begin{array}{l}23.0 \\
23.6\end{array}$ & - \\
\hline $\begin{array}{l}\mathrm{BOD}_{5} \\
\left(\mathrm{mg} \cdot \mathrm{dm}^{-3}\right)\end{array}$ & $\begin{array}{l}1 \\
2\end{array}$ & $\begin{array}{l}4.4 \\
1.7\end{array}$ & $\begin{array}{l}9.5 \\
10.5\end{array}$ & $\begin{array}{l}7.2 \\
4.9\end{array}$ & -32.2 & $\begin{array}{l}1.9 \\
2.3\end{array}$ & $\begin{array}{l}26.9 \\
46.8\end{array}$ & + \\
\hline $\begin{array}{l}\mathrm{COD}_{\mathrm{Cr}} \\
\left(\mathrm{mg} \cdot \mathrm{dm}^{-3}\right)\end{array}$ & $\begin{array}{l}1 \\
2\end{array}$ & $\begin{array}{l}12.0 \\
11.0\end{array}$ & $\begin{array}{l}48.0 \\
48.0\end{array}$ & $\begin{array}{l}37.4 \\
24.1\end{array}$ & -35.6 & $\begin{array}{l}11.9 \\
11.0\end{array}$ & $\begin{array}{l}31.8 \\
45.6\end{array}$ & + \\
\hline $\begin{array}{l}\mathrm{TN} \\
\left(\mathrm{mg} \cdot \mathrm{dm}^{-3}\right)\end{array}$ & $\begin{array}{l}1 \\
2\end{array}$ & $\begin{array}{l}1.10 \\
0.40\end{array}$ & $\begin{array}{l}2.90 \\
1.80\end{array}$ & $\begin{array}{l}1.76 \\
1.16\end{array}$ & -34.3 & $\begin{array}{l}0.7 \\
0.4\end{array}$ & $\begin{array}{l}40.5 \\
35.0\end{array}$ & $(+\alpha=0.10)$ \\
\hline $\begin{array}{l}\mathrm{NH}_{4}^{+} \\
\left(\mathrm{mg} \cdot \mathrm{dm}^{-3}\right)\end{array}$ & $\begin{array}{l}1 \\
2\end{array}$ & $\begin{array}{l}0.04 \\
0.01\end{array}$ & $\begin{array}{l}0.31 \\
0.32\end{array}$ & $\begin{array}{l}0.16 \\
0.14\end{array}$ & -12.0 & $\begin{array}{l}0.1 \\
0.1\end{array}$ & $\begin{array}{l}60.1 \\
78.6\end{array}$ & - \\
\hline $\begin{array}{l}\mathrm{NO}_{3}^{-} \\
\left(\mathrm{mg} \cdot \mathrm{dm}^{-3}\right)\end{array}$ & $\begin{array}{l}1 \\
2\end{array}$ & $\begin{array}{l}0.23 \\
0.15\end{array}$ & $\begin{array}{l}2.65 \\
3.10\end{array}$ & $\begin{array}{l}0.84 \\
1.02\end{array}$ & +21.9 & $\begin{array}{l}0.8 \\
0.8\end{array}$ & $\begin{array}{l}97.3 \\
78.0\end{array}$ & - \\
\hline $\begin{array}{l}\mathrm{NO}_{2}^{-} \\
\left(\mathrm{mg} \cdot \mathrm{dm}^{-3}\right)\end{array}$ & $\begin{array}{l}1 \\
2\end{array}$ & $\begin{array}{l}0.03 \\
0.07\end{array}$ & $\begin{array}{l}0.82 \\
0.76\end{array}$ & $\begin{array}{l}0.28 \\
0.28\end{array}$ & -1.8 & $\begin{array}{l}0.3 \\
0.3\end{array}$ & $\begin{array}{l}116.7 \\
104.6\end{array}$ & - \\
\hline $\begin{array}{l}\text { TP } \\
\left(\mathrm{mg} \cdot \mathrm{dm}^{-3}\right)\end{array}$ & $\begin{array}{l}1 \\
2\end{array}$ & $\begin{array}{l}0.21 \\
0.09\end{array}$ & $\begin{array}{l}3.10 \\
6.37\end{array}$ & $\begin{array}{l}1.05 \\
1.67\end{array}$ & +59.1 & $\begin{array}{l}1.1 \\
2.1\end{array}$ & $\begin{array}{l}102.3 \\
125.6\end{array}$ & - \\
\hline $\begin{array}{l}\mathrm{PO}_{4}{ }^{3-} \\
\left(\mathrm{mg} \cdot \mathrm{dm}^{-3}\right)\end{array}$ & $\begin{array}{l}1 \\
2\end{array}$ & $\begin{array}{l}0.07 \\
0.02\end{array}$ & $\begin{array}{l}1.10 \\
1.63\end{array}$ & $\begin{array}{l}0.39 \\
0.34\end{array}$ & -13.0 & $\begin{array}{l}0.4 \\
0.4\end{array}$ & $\begin{array}{l}94.0 \\
131.0\end{array}$ & - \\
\hline $\begin{array}{l}\mathrm{K}^{+} \\
\left(\mathrm{mg} \cdot \mathrm{dm}^{-3}\right)\end{array}$ & $\begin{array}{l}1 \\
2\end{array}$ & $\begin{array}{l}1.43 \\
1.12\end{array}$ & $\begin{array}{l}20.86 \\
7.07\end{array}$ & $\begin{array}{l}8.85 \\
2.92\end{array}$ & -66.9 & $\begin{array}{l}7.2 \\
1.8\end{array}$ & $\begin{array}{l}81.6 \\
61.2\end{array}$ & $(+\alpha=0.10)$ \\
\hline $\begin{array}{l}\mathrm{Cl}^{-} \\
\left(\mathrm{mg} \cdot \mathrm{dm}^{-3}\right)\end{array}$ & $\begin{array}{l}1 \\
2\end{array}$ & $\begin{array}{l}5.6 \\
4.5\end{array}$ & $\begin{array}{l}747.0 \\
1155.0\end{array}$ & $\begin{array}{l}325.8 \\
392.4\end{array}$ & +20.5 & $\begin{array}{l}333.1 \\
430.9\end{array}$ & $\begin{array}{l}102.3 \\
109.8\end{array}$ & - \\
\hline
\end{tabular}

Table 8 Characteristic values of heavy metals and polycyclic aromatic hydrocarbons in the rainwater reservoir system (R1-R5)

\begin{tabular}{|c|c|c|c|c|c|c|}
\hline $\begin{array}{l}\text { Variables } \\
\left(\mu \mathrm{g} \cdot \mathrm{dm}^{-3}\right)\end{array}$ & Minimal value & Maximum value & Average & Median & Standard deviation & Variation coefficient \\
\hline $\mathrm{Cr}$ & 2.31 & 3.52 & 2.80 & 2.55 & 0.51 & 18.3 \\
\hline $\mathrm{Zn}$ & 5.85 & 10.30 & 7.74 & 7.77 & 1.77 & 22.9 \\
\hline $\mathrm{Cd}$ & $<0.086$ & $<0.086$ & $<0.086$ & $<0.086$ & - & - \\
\hline $\mathrm{Cu}$ & 1.82 & 3.14 & 2.49 & 2.30 & 0.53 & 21.4 \\
\hline $\mathrm{Pb}$ & $<0.132$ & $<0.132$ & $<0.132$ & $<0.132$ & - & - \\
\hline $\mathrm{Ni}$ & 1.16 & 4.09 & 2.00 & 1.67 & 1.19 & 59.4 \\
\hline Fluoranthene & 0.012 & 0.037 & 0.022 & 0.019 & 0.010 & 48.5 \\
\hline Benzo(b)fluoranthene & 0.011 & 0.028 & 0.019 & 0.018 & 0.008 & 45.1 \\
\hline Benzo(k)fluoranthene & 0.004 & 0.011 & 0.008 & 0.008 & 0.004 & 48.7 \\
\hline Benzo(a)pyrene & 0.008 & 0.021 & 0.012 & 0.010 & 0.006 & 50.5 \\
\hline Benzo(g,h,i)perylene & 0.014 & 0.035 & 0.026 & 0.028 & 0.009 & 34.8 \\
\hline Indeno(1,2,3-cd)pyrene & 0.006 & 0.014 & 0.010 & 0.010 & 0.004 & 40.8 \\
\hline
\end{tabular}


found, among other things, that a greater amount of hydrocarbon pollution is contained in rainwater flowing from urbanized areas (Ngabe et al., 2000). The increase in pollution is more related to overloading and car traffic jams than intensity of road traffic. Frequent braking and acceleration conduce to the release of PAHs into the environment (abrasion of tires, exhaust gases) (Liu et al., 2016). It also applies to some heavy metals (Budai \& Clement, 2018). Currently, on the Lublin bypass, traffic flows smoothly and its intensity is much smaller than planned, which is why pollutants such as PAHs or trace elements should not pose a large threat.

\section{Conclusions}

The conducted research showed high variability of rainwater runoff quality from the bypass in the early phase of exploitation of the drainage system (second and third year of functioning of retention reservoirs). In system $\mathrm{R} 1-\mathrm{R} 5, \mathrm{NO}_{2}{ }^{-}, \mathrm{TP}, \mathrm{PO}_{4}{ }^{3-}, \mathrm{K}^{+}$ and $\mathrm{Cl}^{-}$(above 100\%) were characterized by significant differences in concentration. In the majority of measurement dates, retained rainwater was of poor quality. Indicators lowering the quality were mainly conductivity, $\mathrm{BOD}_{5}, \mathrm{COD}, \mathrm{NO}_{2}^{-}$, TP and $\mathrm{Cl}^{-}$. An increase in conductivity was always accompanied by an increase in $\mathrm{Cl}^{-}$concentration. Very high salinity of rainwater runoff could disturb the functioning of freshwater ecosystems during their uncontrolled discharge into the environment. Among nutrients, TP posed the biggest threat. High levels of salt and phosphorus require great caution in the final management of rainwater (threat of salinization and eutrophication). This concerns particularly areas located near valuable water and valley ecosystems under legal protection. It is worth encouraging road administrators in the rational use of salt-including the selection of appropriate doses to prevailing conditions, as well as mechanical removal of snow from shoulders. Retained rainwater was much more polluted in the second year of research (third year of functioning). This applied particularly to conductivity, $\mathrm{NO}_{3}{ }^{-}, \mathrm{NO}_{2}{ }^{-}$, TP and $\mathrm{Cl}^{-}$. Depending on the indicator, differences ranged from $161\left(\mathrm{NO}_{3}{ }^{-}\right)$to $1003 \%$ (TP). Large differences between successive years may result from different weather conditions (high precipitation and dilution in 2016) and gradual accumulation of pollutants in new reservoirs. Rainwater runoff in a cold half-year had higher conductivity, $\mathrm{O}_{2}, \mathrm{NH}_{4}^{+}, \mathrm{NO}_{3}^{-}$and $\mathrm{Cl}^{-}$in relation to a warm half-year. In the second case, higher $\mathrm{COD}$ and $\mathrm{NO}_{2}^{-}$values were recorded. High conductivity and $\mathrm{Cl}^{-}$in a cold half-year is associated with thaw runoffs, carrying with them high loads of contaminants (including anti-snow slipperiness agents). In reservoirs without pre-treatment, there were recorded only higher oxygen demand $\left(\mathrm{BOD}_{5}\right.$ and $\left.\mathrm{COD}\right)$ and higher pollution by $\mathrm{TN}$ and $\mathrm{K}^{+}$than in reservoirs preceded by separators and settlers. However, differences in average amounts of these variables were not high. Due to slight differences in the quality of retained water in reservoirs with and without preliminary treatment, in the future, thorough analyses of the efficiency of settlers and separators and the legitimacy of their use in road rainwater harvesting systems should be carried out. Heavy metals and PAHs burdened rainwater reservoirs to a small degree. However, these components are known for their high durability and the ability to accumulate in the environment. They can effectively pollute areas adjacent to roads. Therefore, in a further part of the research, the monitoring of bottom sediments and areas adjacent to the bypass should additionally be taken into account.

Acknowledgments The authors would like to thank the University of Life Sciences in Lublin for financial support (statutory activity).

Code availability Not applicable.

Authors' contributions Tomasz Zubala: Study design, methodology, data collection, statistical analysis, data interpretation, manuscript preparation, visualization, literature search, supervision

Magdalena Patro: Study design, methodology, data collection, data interpretation, manuscript preparation

Funding The author has not received support from any organization for the submitted work.

Data Availability Not applicable.

\section{Declarations}

Conflict of interest The authors declare that they have no conflict of interest. 
Financial interests The authors have no relevant financial or non-financial interests to disclose.

Open Access This article is licensed under a Creative Commons Attribution 4.0 International License, which permits use, sharing, adaptation, distribution and reproduction in any medium or format, as long as you give appropriate credit to the original author(s) and the source, provide a link to the Creative Commons licence, and indicate if changes were made. The images or other third party material in this article are included in the article's Creative Commons licence, unless indicated otherwise in a credit line to the material. If material is not included in the article's Creative Commons licence and your intended use is not permitted by statutory regulation or exceeds the permitted use, you will need to obtain permission directly from the copyright holder. To view a copy of this licence, visit http://creativecommons.org/licenses/by/4.0/.

\section{References}

Angrill, S., Petit-Boix, A., Morales-Pinzón, T., Josa, A., Rieradevall, J., \& Gabarrell, X. (2017). Urban rainwater runoff quantity and quality - A potential endogenous resource in cities? Journal of Environmental Management, 189, 14-21. https://doi.org/10.1016/j.jenvman.2016.12.027.

Arora, A. S., \& Reddy, A. S. (2015). Conceptualizing a decentralized stormwater treatment system for an urbanized city with improper stormwater drainage facilities. International Journal of Environmental Science and Technology, 12, 2891-2900. https://doi.org/10.1007 /s13762-014-0655-3.

Barbier, L., Suaire, R., Durickovic, I., Laurent, J., \& Simonnot, M. O. (2018). Is a Road Stormwater Retention Pond Able to Intercept Deicing Salt? Water, Air, \& Soil Pollution, 229, 251. https://doi.org/10.1007/s11270-018-3908-9.

Braskerud, B. C., Hartnik, T., \& Løvstad, Ø. (2005). The effect of the redox-potential on the retention of phosphorus in a small constructed wetland. Water Science and Technology, 51(34), 127-134. https://doi.org/10.2166/wst.2005.0583.

Budai, P., \& Clement, A. (2018). Spatial distribution patterns of four traffic-emitted heavy metals in urban road dust and the resuspension of brake-emitted particles: Findings of a field study. Transportation Research Part D: Transport and Environment, 62, 179-185. https://doi.org/10.1016/j. trd.2018.02.014.

Congying, L. (2012). Ecohydrology and good urban design for urban storm water-logging in Beijing, China. Ecohydrology and Hydrobiology, 12(4), 287-300. https://doi.org/10.2478 /v10104-012-0029-8.

Craig, S., \& Zhu, W. (2018). Impacts of Deicing Salt and Nitrogen Addition on Soil Nitrogen and Carbon Cycling in a Roadside Ecosystem. Water, Air, \& Soil Pollution, 229, 187. https://doi.org/10.1007/s11270-018-3838-6.

CSO (Central Statistical Office). (2017). Environment 2017. Warsaw: Statistical Information and Elaborations.
Dojlido, J. (1995). Chemistry of surface waters. Białystok: Ekonomia i Środowisko (in Polish).

Gan, H., Zhuo, M., Li, D., \& Zhou, Y. (2008). Quality characterization and impact assessment of highway runoff in urban and rural area of Guangzhou, China. Environmental Monitoring and Assessment, 140(1-3), 147-159. https://doi. org/10.1007/s10661-007-9856-2.

Geiger, W., \& Dreiseitl, H. (2001). New methods of rainwater drainage. München: Oldenbourg Verlag (in German).

Hossain, M. A., Alam, M., Yonge, D. R., \& Dutta, P. (2005). Efficiency and Flow Regime of a Highway Stormwater Detention Pond in Washington, USA. Water, Air, \& Soil Pollution, 164, 79-89. https://doi.org/10.1007/s11270-0052250-1.

IE (Institute for Eco-development) (2019). Bystrzyca Jakubowicka. Information and Education Portal - Natura 2000 and tourism. http://ine.eko.org.pl/index_areas. php?rek=284. Accessed 15 January 2019. (in Polish)

Imhoff, K., \& Imhoff, K. R. (2006). Handbook of urban drainage. München: Oldenbourg Industrieverlag (in German).

Ivanovsky, A., Belles, A., Criquet, J., Dumoulin, D., Noble, P., \& Alary, \& C., Billon, G. (2018). Assessment of the treatment efficiency of an urban stormwater pond and its impact on the natural downstream watercourse. Journal of Environmental Management, 226, 120-130. https://doi.org/10.1016/j. jenvman.2018.08.015.

Juang, D. F., Tsai, W. P., Liu, W. K., \& Lin, J. H. (2008). Treatment of polluted river water by a gravel contact oxidation system constructed under riverbed. International Journal of Environmental Science and Technology, 5(3), 305-314. https://doi.org/10.1007/BF03326025.

Kabata-Pendias, A., \& Mukherjee, A. B. (2007). Trace elements from soil to human. Springer-Verlag.

Kaszewski, B. M. (2008). Climate. In S. Uziak \& R. Turski (Eds.), Natural environment of the Lublin Region (pp. 75-111). Lubelskie Towarzystwo Naukowe (in Polish).

Klimaszewska, K., Polkowska, Ż., \& Namieśnik, J. (2007). Influence of mobile sources on pollution of runoff waters from roads with high traffic intensity. Polish Journal of Environmental Studies, 16(6), 889-897.

Kuoppamäki, K., Setälä, H., Rantalainen, A.-L., \& Kotze, D. J. (2014). Urban snow indicates pollution originating from road traffic. Environmental Pollution, 195, 56-63. https://doi. org/10.1016/j.envpol.2014.08.019.

Lazur, A., VanDerwerker, T., \& Koepenick, K. (2020). Review of Implications of Road Salt Use on Groundwater Quality Corrosivity and Mobilization of Heavy Metals and Radionuclides. Water, Air, \& Soil Pollution, 231, 474. https://doi.org/10.1007/s11270-020-04843-0.

Le Viol, I., Mocq, J., Julliard, R., \& Kerbiriou, C. (2009). The contribution of motorway stormwater retention ponds to the biodiversity of aquatic acroinvertebrates. Biological Conservation, 142, 3163-3171. https://doi.org/10.1016/j. biocon.2009.08.018.

Lee, J. H., Bang, K. W., Ketchum, L. H., Choe, J. S., \& Yu, M. J. (2002). First flush analysis of urban storm runoff. Science of the Total Environment, 293, 163-175. https://doi. org/10.1016/S0048-9697(02)00006-2.

Liu, L., Liu, A., Li, Y., Zhang, L., Zhang, G., \& Guan, Y. (2016). Polycyclic aromatic hydrocarbons associated with road deposited solid and their ecological risk: Implications for road 
stormwater reuse. Science of the Total Environment, 563564,190-198. https://doi.org/10.1016/j. scitotenv.2016.04.114.

Mangani, G., Berloni, A., Bellucci, F., Tatàno, F., \& Maione, M. (2005). Evaluation of the Pollutant Content in Road Runoff First Flush Waters. Water, Air, \& Soil Pollution, 160, 213228. https://doi.org/10.1007/s11270-005-2887-9.

McGrane, S. J. (2016). Impacts of urbanisation on hydrological and water quality dynamics, and urban water management: a review. Hydrological Sciences Journal, 61(13), 2295-2311. https://doi.org/10.1080/02626667.2015.1128084.

Mikołajków, J., \& Sadurski, A. (2017). Major groundwater reservoirs in Poland. Państwowy Instytut Geologiczny Państwowy Instytut Badawczy (in Polish).

Mokrani, S., Nabti, E., \& Cruz, C. (2020). Current Advances in Plant Growth Promoting Bacteria Alleviating Salt Stress for Sustainable Agriculture. Applied Sciences, 10(20), 7025. https://doi.org/10.3390/app10207025.

Newman, A. P., Aitken, D., \& Antizar-Ladislao, B. (2013). Stormwater quality performance of a macropervious pavement car park installation equipped with channel drain based oil and silt retention devices. Water Research, 47, 73277336. https://doi.org/10.1016/j.watres.2013.05.061.

Ngabe, B., Bidleman, T. F., \& Scott, G. I. (2000). Polycyclic aromatic hydrocarbons in storm runoff from urban and coastal South Carolina. Science of the Total Environment, 255, 19. https://doi.org/10.1016/s0048-9697(00)00422-8.

O'Brien, E. (2006). Habitat fragmentation due to transport infrastructure: Practical considerations. In J. Davenport \& J. L. Davenport (Eds.), The ecology of transportation: managing mobility for the environment (pp. 191-204). Springer.

Ociepa, E., Mrowiec, M., Deska, I., \& Okoniewska, E. (2015). Snow cover as a medium for deposition of pollution. Annual Set The Environment Protection, 17, 560-575 (in Polish).

Peng, H.-Q., Liu, Y., Wang, H.-W., Gao, X.-L., \& Ma, L.-M. (2016). Event mean concentration and first flush effect from different drainage systems and functional areas during storms. Environmental Science and Pollution Research, 23, 5390-5398. https://doi.org/10.1007/s11356-015-5657-2.

Petrucci, G., Gromaire, M.-C., Shorshani, M. F., \& Chebbo, G. (2014). Nonpoint source pollution of urban stormwater runoff: a methodology for source analysis. Environmental Science and Pollution Research, 21, 10225-10242. https://doi.org/10.1007/s11356-014-2845-4.

Polak, M., Wiącek, J., Kucharczyk, M., \& Orzechowski, R. (2013). The effect of road traffic on a breeding community of woodland birds. European Journal of Forest Research, 132(5-6), 931941. https://doi.org/10.1007/s10342-013-0732-z.

Rayski, W., Szymczak, T., \& Mikulska, H. (2010). Construction of the S17 expressway - Section Kurów-Lublin-Piaski - Part 2, Task No. 3. Operat wodno-prawny, DHV Polska Sp. z o.o (in Polish).

Regulation of the Minister of the Environment of 21 July 2016 on the method of classification of the state of uniform parts of surface waters and environmental quality standards for priority substances (Dz.U. 2016, poz. 1187). (in Polish)

Sarkar, S., Ghosh, P., Sil, A. K., \& Saha, T. (2014). Suspended particulate matter dynamics act as a driving force for single pond sewage stabilization system. Ecological Engineering, 69, 206-212. https://doi.org/10.1016/j.ecoleng.2014.03.060.

Song, H., Qin, T., Wang, J., \& Wong, T. H. F. (2019). Characteristics of stormwater quality in Singapore catchments in 9 different types of land use. Water, 11, 2-10. https://doi.org/10.3390/w11051089.

SP (Statistics Poland). (2018). Environment 2018. Statistical Analyses.

Urban, D. (1995). Floristic and faunistic values of the Ciemiega catchment. In T. Orlik, Z. Michalczyk, \& W. Grodzieński (Eds.), The ecological development of Ciemiega river basin (pp. 9-24). Akademia Rolnicza w Lublinie (in Polish).

Vaze, J., \& Chiew, F. (2004). Nutrient loads associated with different sediment sizes in urban stormwater and surface pollutants. Journal of Environmental Engineering, 130, 391-396. https://doi.org/10.1061/(ASCE)0733-9372(2004)130:4(391).

Wakida, F. T., Martinez-Huato, S., Garcia-Flores, E., Piñon-Colin, T. D. J., Espinoza-Gomez, H., \& Ames-López, A. (2014). Pollutant association with suspended solids in stormwater in Tijuana, Mexico. International Journal of Environmental Science and Technology, 11, 319-326. https://doi. org/10.1007/s13762-013-0214-3.

Zhang, K., \& Batterman, S. (2013). Air pollution and health risks due to vehicle traffic. Science of the Total Environment, 450-451, 307-316. https://doi.org/10.1016/j.scitotenv.2013.01.074.

Zhang, Q., Wang, X., Hou, P., Wan, W., Ren, Y., Ouyang, Z., \& Yang, L. (2013). The temporal changes in road stormwater runoff quality and the implications to first flush control in Chongqing, China. Environmental Monitoring and Assessment, 185(12), 9763-9775. https://doi.org/10.1007/s10661-013-3289-x.

Zhang, Q., Wang, X., Hou, P., Wan, W., Li, R., Ren, Y., \& Ouyang, Z. (2014). Quality and seasonal variation of rainwater harvested from concrete, asphalt, ceramic tile and green roofs in Chongqing, China. Journal of Environmental Management, 132, 178-187. https://doi.org/10.1016/j. jenvman.2013.11.009.

Zubala, T. (2013). Analysis of treatment efficiency and the technical and operational conditions of rainwater treatment plant. Gaz, Woda i Technika Sanitarna, 2, 96-98 (in Polish).

Zubala, T. (2018). Technical and natural conditions and operating efficiency of a municipal stormwater treatment plant. Environmental Science and Pollution Research, 25, 952962. https://doi.org/10.1007/s11356-017-0519-8.

Zubala, T., \& Patro, M. (2015). Rainwater reservoirs in the urban landscape - case study. Journal of Ecological Engineering, 16(5), 128-132 https://doi.org/10.12911/22998993/60468.

Zubala, T., Patro, M., \& Boguta, P. (2017). Variability of zinc, copper and lead contents in sludge of the municipal stormwater treatment plant. Environmental Science and Pollution Research, 24, 17145-17152. https://doi. org/10.1007/s11356-017-9338-1.

Publisher's Note Springer Nature remains neutral with regard to jurisdictional claims in published maps and institutional affiliations. 